\section{ekf}

VYSOKÁ ŠKOLA BÁŇSKÁ EKONOMICKÁ FAKULTA

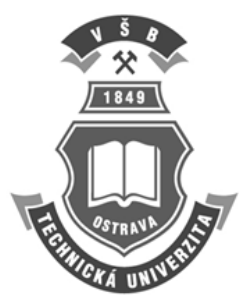

\title{
The efficiency of subsidies for air quality: A case study on the Moravian-Silesian region
}

\author{
Marie PECHROVÁa ${ }^{*}$, Alena KOLÁŘOVÁ \\ a Department of Economics, Faculty of Economics and Management, Czech University of Life Sciences Prague, Kamýcká 129, \\ 16521 Praha 6, Czech Republic.
}

\begin{abstract}
In 2012, the Ministry of the Environment and the Moravian-Silesian region released stove subsidies for the replacement of old household heating boilers to improve the air quality in the Moravian-Silesian region. The aim of the paper is to evaluate the efficiency of providing those finances. A comparison is made of the technical and economic parameters of combustion devices for household heating: a) boilers for coal with hand filling, b) boilers for coal with automatic filling and c) boilers for biomass in relation to $\mathrm{CO}_{2}$ and $\mathrm{NO}_{\mathrm{x}}$ emissions. The best results are provided by the last method. Therefore, it is recommended to extend the subsidies to boilers for biomass combustion, which are not yet supported, in order to expand the positive effect of public support on emission reduction.
\end{abstract}

\section{Keywords}

Operational programme environment, stove subsidies, $\mathrm{CO}_{2}$ emission, air pollution, efficiency.

JEL Classification: Q12, Q14, Q18

*mariepechrova@gmail.com (corresponding author)

The paper is supported by the internal grant Využití finančnich prostředků fondů EU pro rozvoj venkova, No. 20121054: 1110/1312/3112 of the Internal Grant Agency of the Faculty of Economics and Management of the Czech University of Life Sciences in Prague. 


\title{
The efficiency of subsidies for air quality: A case study on the Moravian-Silesian region
}

\author{
Marie PECHROVÁ, Alena KOLÁŘOVÁ
}

\section{Introduction}

The impact of human activities on ecosystems is considerable. The usage of fossil fuels, due to $\mathrm{CO}_{2}$, changes the air and contributes to climate change and to the amplification of the greenhouse effect. According to the IPCC (1997), reducing the risk of catastrophic climatic change requires the stabilisation of the concentration of greenhouse gases to 450-550 ppm of carbon dioxide equivalent - a level considered consistent with an increase on average temperatures not exceeding $2{ }^{\circ} \mathrm{C}$. Hence, the protection of the environment and sustainable behaviour have become issues that have attracted the attention not only of researchers, but also of politicians.

Since the issue of the environment is crosssectional, it has started to be tackled by many policies in the EU. As noted by Schmitt and Schulze (2011), environmental concerns increasingly influence the formulation of the EU's energy policy, especially given the twofold challenge of securing sufficient energy supply whilst also addressing the necessity of combating climate change. The role of the environmental policy is to set procedures or measures that will support positive and limit negative externalities. Public budget expenditures and subsidies given to private subjects for environmental protection are instruments that are an important element of the state policy of environmental protection in developed countries (Jílková, 2003).

All the programmes released by the member states of the EU must be assessed in terms of their impact on the environment. So-called SEA (Strategic Environmental Assessment) must be elaborated before the programme starts.

The effectiveness of political measures in decreasing the emission of greenhouse gases is the subject of various studies. For example, in the study by Delbeke et al. (2010), the possibilities of the EU policy to achieve the goal of $20 \%$ greenhouse gas emission reduction via increasing the share of renewable energy sources in the total energy sources to $20 \%$ by 2020 were analysed. It was concluded that the system of carbon capture and storage in the framework of the EU Emissions Trading Scheme could lead to significant cost savings. In Jaraité and Corrado's (2012) research, the environmental efficiency and productivity of the public power generating sector were measured and the effectiveness of the carbon pricing measure and Emissions Trading Scheme were assessed in relation to decreasing $\mathrm{CO}_{2}$ emissions. The conclusion reached was that carbon pricing leads to an increase in environmental efficiency and to an outward shift of the technological frontier and that the overly generous allocation of emission permits has a negative impact on both measures (Jaraité and Corrado, 2012). According to Dandres et al. (2012), the EU's bioenergy politics has a positive impact. Its absence would cause a negative influence on human activities and would affect people's health. Furthermore, the lack of EU environmental policy would have negative consequences for global heating and environmental resources at the EU and global levels.

The analysis in this paper is focused particularly on the structural policy and its operational programme Environment (OP Envi), in which 4.92 bil. euros were available for the CR in the programming period 20072013 (Funds EU, 2012). OP Envi supports the protection and improvement of the environmental quality, which is the basis for people's health and contributes to the increasing attractiveness of the CR for life, work and investment and thus supports its overall competitiveness (Funds EU, 2012; OP Envi, 2010). The improvement of the air quality is achieved by reducing the $\mathrm{CO}_{2}$ and $\mathrm{NO}_{\mathrm{x}}$ emissions. The second most important polluter after transport in the Czech Republic is households. According to the Ministry of Environment (MoE, 2012a), they contributed 31\% of the total dust production in 2011.

The worst situation is in the Moravian-Silesian region (MSR). Despite the reduction of industrial production, the new legislative measures and investments in ecological and environment-friendly technologies over the past 90 years, which led to the improvement of the situation, the inhabitants of this region are still confronted with an excessive burden of air with solid pollutants and carcinogenic substances (airborne dust and benzoapyren). The majority of the MSR belongs to an area with deteriorated air quality. There are four areas of pollution sources in the MSR; the procedures for eliminating them are defined. One source is households, because the region is atypical in its settlement 
structure and the so-called Silesian build-up area, where the majority of locals live in family houses. Households (479 530) are mostly heated by natural gas $(34.3 \%)$, then by district heating $(49.4 \%)$ and coal (10.1\%) (Cenia, 2009). Therefore, the MoE introduced a set of measures in the framework of action plans in order to improve the air quality in the region.

At the beginning of 2012, the MoE, in cooperation with the MSR, provided finances for changing the current manually filled boilers for solid fuels to new, low-emission, automatic boilers for coal or for coal and biomass. The so-called stove subsidies should have contributed to decreasing the environmental pollution from small, local, stationary combustion, in which non-quality fuels and waste are often incinerated by households. Therefore, the inhabitants were motivated by the subsidies programme to switch their current heating methods for more ecological ones. The maximal subsidy was set at 60 thousand CZK for one new, efficient, low-emission automatic boiler. The eligible costs included the purchase and installation of a new, low-emission, automatic boiler that fulfilled the stated marginal emission level and minimal efficiency requirement (ČSN EN 303-5, emission class 3) (MoE, 2012b).

The MoE supports investments in the insulation of private and public buildings and heat production from renewable energy resources. The provision of financial means for local furnaces via grant programmes supported the change of manually filled boilers for solid fuels to low-emission, automatic boilers.

The aim of our analysis is to assess the efficiency of the stove subsidy programme implemented in the Moravian-Silesian region in 2012 in order to improve the air quality.

The structure of the paper is the following. Firstly, the methodology and data sources used are presented. In the results section, the total emissions of $\mathrm{CO}_{2}$ and $\mathrm{NO}_{x}$ produced by various heating methods are calculated. Consequently, they are placed in the context of the subsidy programme. Finally, the efficiency of the subsidies is assessed. The last section summarizes the results.

\section{Data and methodology}

The efficiency analysis deals with a particular subsidy programme funding the replacement of boilers with more environmentally friendly ones in terms of the reduction of $\mathrm{CO}_{2}$ and $\mathrm{NO}_{\mathrm{x}}$ emissions. $\mathrm{CO}_{2}$ and $\mathrm{NO}_{\mathrm{x}}$ emissions are monitored in detail during the whole process from fuel production to combustion.

The examination was performed on the case study of the MSR. As shown by Ježek (2005), the main problem of case studies is their theoretical construc- tion and especially their theoretical generalization, i.e. the extent to which the findings gained from the study of one case can be marked as generally valid. With this in mind, in this study, a case study concerning the mere introduction to the problem, with the aim of tackling the problem not only in the MSR, is considered urgent. Alternative methods of heating in the MSR are assessed. The following simulation is performed by means of general data. Secondary data are gathered from programme and strategic documents and technical studies and sorted for consequent exploration. The technical and economic parameters of three different technologies of combustion devices used for household heating are compared: a) classical boilers for coal with hand filling, b) boilers for coal with automatic filling and c) boilers for wood pellets. The demand for electric energy consumption of the main production process and support processes of each alternative are assessed. The emissions of $\mathrm{CO}_{2}$ and $\mathrm{NO}_{\mathrm{x}}$ that emerged as the result of the combustion of coal and wooden pellets for an ordinal family house with heat loss of about $17 \mathrm{~kW}$ are calculated. In the final synthesis, the subsidies' efficiency in the MSR are assessed in relation to the savings of $\mathrm{CO}_{2}$ and $\mathrm{NO}_{\mathrm{x}}$ emissions. The determination of the terminology and technical data set is based on the definition anchored in standards ISO 12831 Method for calculation of the design heat load, ISO 13790 Thermal performance of buildings - Calculation of energy use for space heating and TNI 730331 Technical normalization information. The quantities and units used with descriptions are displayed in Table 1.

Table 1 Terminology

\begin{tabular}{|l|c|l|}
\hline Quantity & Unit & \multicolumn{1}{|c|}{ Description } \\
\hline $\begin{array}{l}\text { Annual heat } \\
\text { consumption }\end{array}$ & {$[\mathrm{GJ}]$} & $\begin{array}{l}\text { Heat consumption for house- } \\
\text { hold heating }\end{array}$ \\
\hline $\begin{array}{l}\text { Annual heat } \\
\text { consumption }\end{array}$ & {$[\mathrm{MWh}]$} & $\begin{array}{l}\text { Heat consumption for house- } \\
\text { hold heating }\end{array}$ \\
\hline $\begin{array}{l}\text { Heating val- } \\
\text { ue/calorific } \\
\text { value }\end{array}$ & {$[\mathrm{MJ} / \mathrm{kg}]$} & $\begin{array}{l}\text { The amount of heat in 1 kg of } \\
\text { fuel (indicator of the fuel } \\
\text { quality); a higher value im- } \\
\text { plies a higher amount of heat }\end{array}$ \\
\hline $\begin{array}{l}\text { Boiler efficien- } \\
\text { cy }\end{array}$ & {$[\%]$} & $\begin{array}{l}\text { The ratio of utilized heat in } \\
\text { the fuel to the total amount of } \\
\text { heat }\end{array}$ \\
\hline $\begin{array}{l}\text { Annual fuel } \\
\text { consumption }\end{array}$ & $\begin{array}{l}\text { This depends on the calorific } \\
\text { value and combustion effi- } \\
\text { ciency }\end{array}$ \\
\hline $\begin{array}{l}\text { Total heat in } \\
\text { fuel }\end{array}$ & {$[\mathrm{GJ}]$} & $\begin{array}{l}\text { The total amount of heat in } \\
\text { the fuel (including the not- } \\
\text { fully utilized part) = annual } \\
\text { calorific value }\end{array}$ \\
\hline $\begin{array}{l}\text { Annual CO } \\
\text { emission during } \\
\text { combustion }\end{array}$ & {$[\mathrm{t}]$} & $\begin{array}{l}\text { For coal: } 81.3 \mathrm{~kg} \text { CO } \\
\text { sions for 1 GJ of heat in fuel }\end{array}$ \\
\hline
\end{tabular}

Source: ČSN EN 12831 (2005), TNI 730331 (2013), ČSN

EN ISO 13790 (2009), own elaboration 
In the final synthesis, the efficiency of the usage of the subsidies in support of automatic boilers in the MSR is calculated in relation to the emissions savings of $\mathrm{CO}_{2}$ and $\mathrm{NO}_{\mathrm{x}}$. Ratio indexes are used to this end. On the basis of the results, recommendations are formulated for policy makers.

\section{Results of the analysis}

The following sections compare the $\mathrm{CO}_{2}$ and $\mathrm{NO}_{\mathrm{x}}$ emissions for three types of combustion devices used for the heating of households.

\subsection{Comparison of $\mathrm{CO}_{2}$ emissions from combus- tion devices for heating}

Firstly, the $\mathrm{CO}_{2}$ emissions are compared for three types of combustion devices used for the heating of households. $\mathrm{CO}_{2}$ is observed during the phases of fuel production and consequent combustion during heating. Two variants are considered in the case of boilers for coal: hand filling and automatic filling. The $\mathrm{CO}_{2}$ emissions released during coal production are not considered.

During the pellet production, the material is first crushed in a crusher and then compressed in a pelletizing press. The power of the chosen crusher was $15 \mathrm{~kW}$ and the power of the press was $30 \mathrm{~kW}$; with a yield of both devices of $1 \mathrm{t}$ per hour, the consumption of electric energy was equal to $45 \mathrm{kWh}$ for 1 ton of produced pellets (Peletovací lisy, 2012). Note that the energy consumption was calculated with professional devices. They are more widely used and more efficient than devices used for hobby purposes.

The average emissions per $1 \mathrm{MWh}(=1000$ $\mathrm{kWh}$ ) of produced electricity are 0.950 tons of $\mathrm{CO}_{2}$ in the $\mathrm{CR}$ for all energetic systems (power stations for fossil fuels and renewable sources) (Covenant of Mayors for Local Sustainable Strategy, 2008). During the production of 1 ton of pellets, $42-48 \mathrm{kWh}$ of energy is consumed, while during production, on average 0.043 tons of $\mathrm{CO}_{2}$ emissions are released into the air. The calculations are presented in Table 2.

Firstly, it is necessary to calculate the detailed energetic balance in order to assess the amount of fuel needed for heating a particular building. A house with heat loss of $17 \mathrm{~kW}$ was considered for this calculation - i.e. a house that corresponds to the average old house without thermal insulation in which a coal boiler is the most common source of heating. The average need for heat of this type of house is approximately $100 \mathrm{GJ}$ per year. It is possible to calculate this value from the average temperature in the heating season and the average outdoor temperature. According to the producer, this amount of heat can be covered by 10.1 tons of brown coal or 6.9 tons of pellets.
In the former case, using a brown coal manual boiler with $55 \%$ efficiency or an automatic boiler with $80 \%$ efficiency gives an average heating value of $18 \mathrm{MJ} / \mathrm{kg}$. The latter method is $85 \%$ efficient, but provides only $17 \mathrm{MJ} / \mathrm{kg}$.

Table $2 \mathrm{CO}_{2}$ emission - production of 1 ton of pellets

\begin{tabular}{|l|c|c|c|}
\hline & $\begin{array}{c}\text { Wood } \\
\text { crushing }\end{array}$ & Pelleting & Total \\
\hline Type of devices [-] & KVX150 & KV400 & \\
\hline Power [kW] & 15 & 30 & 45 \\
\hline Yield [kg/h] & 1000 & $900-1100$ & \\
\hline $\begin{array}{l}\text { Energy consumption } \\
\text { per 1 t of pellets } \\
{[\mathrm{kWh}]}\end{array}$ & 15 & $27-33$ & $42-48$ \\
\hline $\begin{array}{l}\mathrm{CO} \text { emissions for } \\
\text { production of 1 t of } \\
\text { pellets [t] }\end{array}$ & 0.014 & $\begin{array}{c}0.026- \\
0.031\end{array}$ & 0.043 \\
\hline
\end{tabular}

Source: The Covenant of Mayors for Local Sustainable Strategy (2008), ČSN EN ISO 13790 (2009), Koloničný (2010), Peletovací lisy (2012), own elaboration on data from 2010 and 2012

The calculation of $\mathrm{CO}_{2}$ emissions during consumption for different types of boilers is shown in Table 3 .

Table 3 Annual heat and fuel consumption of an older house (heat loss $17 \mathrm{~kW}$ )

\begin{tabular}{|c|c|c|c|}
\hline \multirow{2}{*}{$\begin{array}{l}\text { The type of boiler } \\
\text { (fuel supply) }\end{array}$} & \multicolumn{2}{|c|}{ Brown coal } & Pellets \\
\hline & $\begin{array}{c}\text { man- } \\
\text { ual }\end{array}$ & $\begin{array}{l}\text { auto- } \\
\text { matic }\end{array}$ & $\begin{array}{l}\text { auto- } \\
\text { matic }\end{array}$ \\
\hline Annual heat consumption [GJ] & \multicolumn{3}{|c|}{100} \\
\hline Annual heat consumption [MWh] & \multicolumn{3}{|c|}{27.8} \\
\hline Annual fuel consumption $[t]$ & 10.1 & 6.9 & 6.9 \\
\hline Boiler efficiency $[\%]$ & 55 & 80 & 85 \\
\hline Heating value $[\mathrm{MJ} / \mathrm{kg}]$ & \multicolumn{2}{|c|}{18} & 17 \\
\hline Total heat in fuel [GJ] & 181.8 & 124.2 & 117.3 \\
\hline $\begin{array}{l}\text { Annual } \mathrm{CO}_{2} \text { emission during } \\
\text { combustion }[\mathrm{t}]\end{array}$ & 14.76 & 10.09 & 0 \\
\hline
\end{tabular}

Source: Koloničný (2010), TZBinfo (2012), own elaboration on data from 2010 and 2012

During brown coal combustion, $\mathrm{CO}_{2}$ that was accumulated millions of years ago is released. This negatively influences the volume of $\mathrm{CO}_{2}$ in the atmosphere. The amount of $\mathrm{CO}_{2}$ released during brown coal combustion is, according to the Covenant of Mayors for Local Sustainable Strategy (2008), $81.3 \mathrm{~kg}$ in $1 \mathrm{GJ}$ of fuel. During consumption of 181.8 GJ per year, 14.76 tons of $\mathrm{CO}_{2}$ are released by a boiler with manual filling of fuel. In the case of a boiler with automatic filling of fuel, the amount of $\mathrm{CO}_{2}$ is lower thanks to its higher combustion efficiency -10.09 tons.

In contrast, during pellet combustion, exactly the same amount of $\mathrm{CO}_{2}$ emissions is released into the air as the plant had absorbed during its growth. The com- 
bustion of pellets (or any plant biomass in general) is therefore neutral in terms of the release of $\mathrm{CO}_{2}$ emissions.

The associated emissions from transport and mining of raw materials are not taken into account in the calculation. However, they will also be higher in the case of coal mining. The energy used for coal mining is higher than that for biomass production, which is often gained as industry or agriculture waste, and a larger amount of coal fuel also needs to be transported to the household.

Secondly, the total amount of $\mathrm{CO}_{2}$ emissions released to the air during the annual fuel consumption is calculated. The emissions produced during the production and combustion of the fuel are summarized and displayed in Table 4. It can be clearly seen that if a heating system with an old boiler for brown coal is changed to a heating system with pellets, the $\mathrm{CO}_{2}$ emissions of an average house will decrease by 14.4633 (14.76 minus 0.2967 ) tons every year.

Table 4 Annual $\mathrm{CO}_{2}$ emissions during fuel consumption

\begin{tabular}{|l|c|c|c|}
\hline \multirow{2}{*}{$\begin{array}{l}\text { The type of boiler with annual } \\
\text { fuel consumption (fuel supply) }\end{array}$} & \multicolumn{2}{|c|}{ Brown coal } & Pellets \\
\cline { 2 - 4 } & manual & $\begin{array}{l}\text { auto- } \\
\text { matic }\end{array}$ & $\begin{array}{c}\text { auto- } \\
\text { matic }\end{array}$ \\
\hline Annual fuel consumption [t] & 10.1 & 6.9 & 6.9 \\
\hline Fuel production [t] & - & - & 0.2967 \\
\hline Fuel combustion [t] & 14.76 & 10.09 & 0 \\
\hline $\begin{array}{l}\text { Total annual } \mathrm{CO}_{2} \text { emissions* } \\
{[\mathrm{t}]}\end{array}$ & 14.76 & 10.09 & 0.2967 \\
\hline
\end{tabular}

Emissions released during raw material mining and transportation are not included.

Source: Koloničný (2010), TZBinfo (2012), own elaboration on data from 2010 and 2012

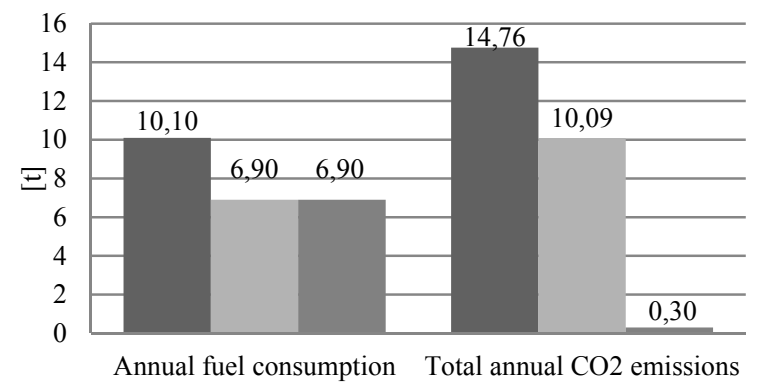

- Brown coal manual $₫$ Brown coal automatic - Pellets automatic
As can be seen in Figure 1, the annual fuel (coal) consumption reduction (by 3.20 tons) is caused by putting a brown coal automatic stove into service. As well as in the previous case, the same amount of fuel (6.9 tons of pellets), and thus similar fuel saving, is needed for heating by an automatic pellets stove.

\subsection{Comparison of $\mathrm{NO}_{\mathrm{x}}$ emissions from combus- tion devices for heating}

During brown coal combustion, apart from $\mathrm{CO}_{2}$, other polluters are released to the atmosphere (sulphur and nitrogen oxides, dust). The amount of nitrogen oxides released is calculated analogically to the amount of $\mathrm{CO}_{2}$ released. During brown coal combustion, on average $161 \mathrm{~g}$ of $\mathrm{NO}_{\mathrm{x}}$ are released per $1 \mathrm{GJ}$ in fuel; during biomass combustion, the emissions are lower $120 \mathrm{~g}$ of $\mathrm{NO}_{\mathrm{x}}$ for $1 \mathrm{GJ}$ in fuel. Therefore, when recalculating the amount of the annual fuel consumption, the total heat in the fuel is $181.8 \mathrm{GJ}$ in the case of brown coal and a boiler with manual filling, $124.2 \mathrm{GJ}$ when a boiler with automatic filling is used and finally pellets provide only 117.3 GJ of heat. The detailed calculation is displayed in Table 5 .

Table 5 Annual $\mathrm{NO}_{\mathrm{x}}$ emission during fuel consumption

\begin{tabular}{|l|c|c|c|}
\hline \multirow{2}{*}{$\begin{array}{l}\text { The type of boiler } \\
\text { (fuel supply) }\end{array}$} & \multicolumn{2}{|c|}{ Brown coal } & Pellets \\
\cline { 2 - 4 } & manual & $\begin{array}{l}\text { auto- } \\
\text { matic }\end{array}$ & $\begin{array}{c}\text { auto- } \\
\text { matic }\end{array}$ \\
\hline Annual fuel consumption [t] & 10.1 & 6.9 & 6.9 \\
\hline Total heat in fuel [GJ] & 181.8 & 124.2 & 117.3 \\
\hline $\begin{array}{l}\mathrm{NO}_{\mathrm{x}} \text { emission during combus- } \\
\text { tion [kg] }\end{array}$ & 29.3 & 20.0 & 14.1 \\
\hline
\end{tabular}

Source: Koloničný (2010), TZBinfo (2012), own elaboration on data from 2010 and 2012

As it is obvious from the calculations, the emissions released are the lowest in the last case. Only around $14.1 \mathrm{~kg}$ of $\mathrm{NO}_{\mathrm{x}}$ is produced during pellets' combustion, while the values for brown coal are twice as high for manually filled boilers $(29.3 \mathrm{~kg})$.

\section{Discussion}

The efficiency of subsidies from OP Envi is assessed as the amount of $\mathrm{CO}_{2}$ and $\mathrm{NO}_{\mathrm{x}}$ emissions reduced by $1 \mathrm{CZK}$ of support. The results of the analysis for $\mathrm{CO}_{2}$ and $\mathrm{NO}_{\mathrm{x}}$ emissions are displayed in Table 6. In the

Figure 1 Comparison of boilers' characteristics

Table 6 Efficiency of subsidies to the $\mathrm{CO}_{2}$ and the $\mathrm{NO}_{\mathrm{x}}$ emissions recalculated per beneficiary

\begin{tabular}{|c|c|c|c|c|c|c|c|c|}
\hline \multirow{2}{*}{$\begin{array}{l}\text { Subsidy } \\
\text { (mil. } \\
\text { CZK) }\end{array}$} & \multicolumn{2}{|c|}{$\begin{array}{l}\text { Annual } \mathrm{CO}_{2} \text { emissions } \\
\text { savings ( } \mathrm{kg} / \text { household) in } \\
\text { the case of transition to }\end{array}$} & \multicolumn{2}{|c|}{$\begin{array}{c}\text { Efficiency of } 1 \mathrm{CZK} \text { subsi- } \\
\text { dy }\left(\mathrm{CZK} / \mathrm{kg} \mathrm{CO} \mathrm{CO}_{2}\right) \text { in the } \\
\text { case of transition to }\end{array}$} & \multicolumn{2}{|c|}{$\begin{array}{c}\text { Annual } \mathrm{NO}_{x} \text { emissions } \\
\text { savings }(\mathrm{kg} / \text { household) in } \\
\text { the case of transition to }\end{array}$} & \multicolumn{2}{|c|}{$\begin{array}{c}\text { Efficiency of } 1 \mathrm{CZK} \text { subsi- } \\
\text { dy }(C Z K / \mathrm{kg} \mathrm{NO}) \text { in the } \\
\text { case of transition to }\end{array}$} \\
\hline & $\begin{array}{l}\text { coal stove } \\
\text { automatic }\end{array}$ & $\begin{array}{c}\text { pellet stove } \\
\text { automatic }\end{array}$ & $\begin{array}{l}\text { coal stove } \\
\text { automatic }\end{array}$ & $\begin{array}{c}\text { pellet stove } \\
\text { automatic }\end{array}$ & $\begin{array}{l}\text { coal stove } \\
\text { automatic }\end{array}$ & $\begin{array}{c}\text { pellet stove } \\
\text { automatic }\end{array}$ & $\begin{array}{l}\text { coal stove } \\
\text { automatic }\end{array}$ & $\begin{array}{c}\text { pellet stove } \\
\text { automatic }\end{array}$ \\
\hline 0.06 & 4670 & 14463 & 0.0778 & 0.2411 & 9.3 & 15.20 & 0.0002 & 1.6344 \\
\hline
\end{tabular}

Source: The Moravian-Silesian region and MoE (2012), own elaboration on data from 2012 
framework of the subsidy programme for the replacement of old boilers for solid fuels, $19.98 \mathrm{mil}$. CZK were allocated to 333 beneficiaries in the MSR. This means that the average support per beneficiary was $60000 \mathrm{CZK}$. Changing one boiler for coal with manual filling to a boiler with automatic filling brings savings of at least $4670 \mathrm{~kg}$ in the case of $\mathrm{CO}_{2}$ and $9.3 \mathrm{~kg}$ in the case of $\mathrm{NO}_{\mathrm{x}}$ per household. In total, the change of boilers might have produced $\mathrm{CO}_{2}$ emissions savings of $1555110 \mathrm{~kg}$ and $\mathrm{NO}_{\mathrm{x}}$ emissions savings of 3096.9 $\mathrm{kg}$, suggesting that the subsidies had a positive impact.

The annual emissions savings could have been even higher if the old manually filled boilers had been replaced with automatic boilers for pellets. The total amount for all the programme's beneficiaries might have been $4816279 \mathrm{~kg}$ for $\mathrm{CO}_{2}$ and $5061.6 \mathrm{~kg} \mathrm{NO}$ emissions. However, it is only a hypothetical calculation as automatic boilers for pellets were not supported within the framework of the stove subsidy programme. Therefore, the recommendation of this study is to broaden the scope of the subsidies to boilers for biomass, which would contribute to a higher emission reduction.

Regarding the public support, $1 \mathrm{CZK}$ of subsidies causes a $\mathrm{CO}_{2}$ reduction of $0.0778 \mathrm{~kg}$ when the transition to automatic boilers for coal is supported and $0.2411 \mathrm{~kg}$ if the transition to automatic boilers for pellets had taken place. The results are similar in the case of $\mathrm{NO}_{\mathrm{x}}$ emissions. Again, the transition to automatic boilers for pellets would contribute to higher pollution reduction. While $1 \mathrm{CZK}$ brings a reduction of $\mathrm{NO}_{\mathrm{x}}$ of $0.0002 \mathrm{~kg}$ when the change of manual boilers to automatic ones is supported, the same amount of money could cause a decline of $1.6344 \mathrm{~kg}$ of $\mathrm{NO}_{\mathrm{x}}$ if the boilers for pellets were supported.

It has been proved that the so-called stove subsidies aimed at households in the MSR are efficient in terms of $\mathrm{CO}_{2}$ and $\mathrm{NO}_{\mathrm{x}}$ emission reduction. Only minimal levels of $\mathrm{CO}_{2}$ and $\mathrm{NO}_{\mathrm{x}}$ emission savings were calculated; the real ones could be different. The simulation did not take into account the impossibility of combustion in new boilers with automatic filling of all (including inappropriate) household communal waste, as used to be possible in the case of old boilers. Therefore, the real emissions' savings might be even higher.

\section{Conclusion}

The aim of the paper was to assess the efficiency of the public finances devoted to the $\mathrm{CO}_{2}$ and $\mathrm{NO}_{\mathrm{x}}$ reduction in the MRS. The efficiency of subsidies from the European Union's thematic Operational Programme Environment co-financed by the Moravian-Silesian region was examined. The so-called stove subsidies were taken into account in the evaluation. They were aimed at the replacement of manually filled boilers for solid fuels with new, low-emission, automatic boilers for coal or for coal and biomass. The efficiency of financial means was proved by the analysis as the replacement brought a significant reduction in $\mathrm{CO}_{2}$ and $\mathrm{NO}_{\mathrm{x}}$ emissions. The purchase of new heating technologies for households leads to a total effect of emission reduction in the region and improvement of the environment. Savings of $\mathrm{CO}_{2}$ emissions as high as $0.0778 \mathrm{~kg}$ and $\mathrm{NO}_{\mathrm{x}}$ emissions of $0.0002 \mathrm{~kg}$ were achieved by 1 CZK spent on the transition of a household to a boiler for coal with automatic filling. The effect would be larger if the support was also aimed at boilers for biomass combustion only. However, OP Envi and the MSR supported exclusively boilers for coal with automatic filling or boilers for coal and biomass. Support for pellets boilers of $1 \mathrm{CZK}$ would bring a $\mathrm{CO}_{2}$ emission reduction of $0.2441 \mathrm{~kg}$ and a $\mathrm{NO}_{\mathrm{x}}$ emission reduction of $1.6344 \mathrm{~kg}$.

Therefore, the introduction of subsidies for boilers for biomass only is also recommended by this study. This would multiply the positive effect of financial means from OP Envi and regional subsidies on the emission reduction and would increase the air quality in the MSR. The same or an even higher effect might be achieved if the current legislation was toughened. However, a more detailed analysis would exceed the framework of this study, so this topic is left as a challenge for future research and it is supposed that the government will prefer to motivate people with positive incentives rather than with sanctions. Moreover, law enforcement is not without costs.

\section{References}

DANDRES, D. et al. (2012). Macroanalysis of the economic and environmental impacts of a 2005-2025 European Union bioenergy policy using the GTAP model and life cycle assessment. Renewable and Sustainable Energy Reviews 16(2): 1180-1192. http://dx.doi.org/10.1016/j.rser.2011.11.003

DELBEKE, J. et al. (2010). The Role of Environmental Economics in Recent Policy Making at the European Commission. Review of Environmental Economics and Policy 4(1): 24-43.

http://dx.doi.org/10.1093/reep/rep020

JARAITÉ, J., CORRADO, D. M. (2012). Efficiency, productivity and environmental policy: A case study of power generation in the EU. Energy Economics 34(5): 1557-1568.

http://dx.doi.org/10.1016/j.eneco.2011.11.017

JEŽEK, J. (2005). Regionální management jako nový př́stup k regionálnímu rozvoji. In: VIII. mezinárodni kolokvium o regionálních védách. Brno: Masarykova univerzita, 37-47. 
JíLKOVÁ, J. (2003). Daně, dotace a obchodovatelná povolení - nástroje ochrany ovzduši a klimatu. Praha: IREAS.

SCHMITT, S., SCHULZE, K. (2011). Choosing environmental policy instruments: An assessment of the „environmental dimension” of EU energy policy, European Integration Online Papers-EIOP 15: N/A.

\section{Additional sources}

CENIA (2009). Stav životniho prostředí v jednotlivých krajich České republiky: Moravskoslezský kraj. [Online], accessed at 20. 01. 2013. Available from: $<$ http://www.cenia.cz/web/www/web-pub2.nsf/\$pid/ CENAXG4NILTD/\$FILE/Moravskoslezsk\%C3\%BD. pdf?.

ČSN EN 12831 (2005). Tepelné soustavy v budovách - Výpočet tepelného výkonu. Úřad pro technickou normalizaci, metrologii a státní zkušebnictví, 91.140.10.

ČSN EN 303-5 (075303) (2013). Kotle pro ústředni vytápění - Část 5: Kotle pro ústřední vytápění na pevná paliva, s ruční a samočinnou dodávkou, o jmenovitém tepelném výkonu nejvýše $500 \mathrm{~kW}-$ Terminologie, požadavky, zkoušeni a značení. Úřad pro technickou normalizaci, metrologii a státní zkušebnictví, ICS 01.040.91; 91.140.10.

ČSN EN ISO 13790 (2009). Tepelné chováni budovVýpočet potřeby energie na vytápění a chlazení. Úřad pro technickou normalizaci, metrologii a státní zkušebnictví, ICS 91.120.10.

FUNDS EU (2012). Tematické operační programy. [On-line], accessed at 19. 01. 2013. Available from: $<$ http://www.strukturalni-fondy.cz/cs/Fondy-EU/ Programy-2007-2013/Tematicke-operacni-programy>. IPCC (1997). Revised 1996 IPCC guidelines for national greenhouse gas inventories: Reporting instruction (Volume 1). Technical report. Intergovernmental Panel on Climate Change. [On-line], accessed at 10. 04. 2014. Available from: <http://www.ipcc-nggip. iges.or.jp/public/gl/invs4. html>.

KOLONIČNÝ, J. (2010). Emise při spalováni biomasy. [On-line], accessed at 20. 01. 2013. Available from: $\quad<$ http://biom.cz/cz/odborne-clanky/emise-prispalovani-biomasy-2>.

MoE (MINISTRY OF THE ENVIRONMENT) (2012a). V ČR na znečištováni ovzduši vévodí doprava a domácnosti. [On-line], accessed at 15. 08. 2013. Available from: <http://www.mzp.cz/cz/news_120316 MSK>.

MoE (MINISTRY OF THE ENVIRONMENT) (2012b). Akčni plán MŽP pro Moravskoslezský kraj. [On-line], accessed at 29. 04. 2014. Available from: $<$ http://www.mzp.cz/cz/akcni_plan_msk_2012>.

MORAVIAN-SILESIAN REGION AND MoE (MINISTRY OF THE ENVIRONMENT) (2012). Společná výzva k podáváni žádostí o poskytnutí dotace. [Online], accessed at 29. 04. 2014. Available from: $<\mathrm{http}$ //verejna-sprava.kr-moravskoslezsky.cz/as sets/granty/4-spolecna_vyzva_mzp_a_msk.pdf $>$.

OP Envi (OPERATIONAL PROGRAMME ENVIRONMENT) (2010). Závazné pokyny pro žadatele a př́jemce podpory z OPŽP. [On-line], accessed at 29. 04. 2014. Available from: <http://www.opzp.cz/ soubor-ke-stazeni/33/9948-20100429_zppz.pdf $>$.

PELETOVACI LISY (2012). Peletovaci lisy a drtiče, [On-line], accessed at 20. 12. 2012. Available from: $<$ http://www.peletovaci-lisy.cz>.

THE COVENANT OF MAYORS FOR LOCAL SUSTAINABLE STRATEGY (2008). Committed to local sustainable energy: Technical annex for fillingin of SEAP template. [On-line], accessed at 18. 12. 2012. Available from: <http://www.eumayors.eu/ IMG/pdf/technical_annex_cs.pdf $>$.

TNI 730331 (2013). Energetická náročnost budov Typické hodnoty pro výpočet. Úřad pro technickou normalizaci, metrologii a státní zkušebnictví, ICS 07.060; 91.120.01.

TZBINFO (2012). Porovnáni nákladů na vytápění podle druhu paliva. [On-line], accessed at 20. 01. 2013. Available from: <http://vytapeni.tzb-info.cz/ tabulky-a-vypocty/269-porovnani-nakladu-navytapeni-podle-druhu-paliva>. 
